\title{
Domuz Jelatinine Özgü DNA Aptamerlerinin Seçilimi ve Karakterizasyonu
}

\author{
Abdullah Tahir BAYRAÇ ${ }^{* 1}$, Berke Bilgenur KANDEMİR ${ }^{1}$ \\ ${ }^{1}$ Karamanoğlu Mehmetbey Üniversitesi, Mühendislik Fakültesi, Biyomühendislik Bölümü, 70100, Karaman
}

(Alınıș / Received: 16.05.2017, Kabul / Accepted: 28.09.2017, Online Yayınlanma / Published Online: 30.10.2017)

Anahtar Kelimeler

Aptamer,

SELEX,

Jelatin,

Domuz
Özet: Aptamerler farklı hedeflere yüksek etkin ve özgünlükte bağlanabilen DNA ve RNA moleküllerdir. Bu çalışmada domuz jelatininin algılanmasında kullanılmak üzere DNA aptamerleri geliştirilmiştir. Aptamerlerin seçilimi için tekrarlı, negatif seçilim bulunan bir SELEX metodu takip edilmiş ve kütüphaneler bu yolla zenginleștirilmiștir. Zenginleştirilen kütüphaneler tarafımızca modifiye edilmiş bir metagenomik dizileme metodu kullanılarak yeni nesil dizileme sistemi Miseq ile dizilenmiş ve elde edilen yüksek hacimli veriden aday aptamer dizileri uygun biyoinformatik araçlar kullanılarak belirlenmiştir. Floresan modifiye olarak üretilen aday DNA aptameri domuz jelatinine karşı yüksek afinite göstermekte balık ve sığır jelatinine görece düşük afinite ile bağlanmaktadır. Bu çalışmada geliştirilen aptamer gıda tağşişlerinin belirlenmesi için kullanılacak sensörlerin geliştirilmesinde potansiyel algılama ajanı olarak kullanılabilecektir.

\section{Selection and Characterization of Porcine Gelatine Specific DNA Aptamers}

Keywords

Aptamer,

SELEX,

Gelatine,

Porcine

\begin{abstract}
Aptamers are DNA or RNA molecules that can bind to their target in high affinity and specificity. In this study we developed DNA aptamers to use in the detection of porcine gelatine. Selection of aptamers was performed by repetitive SELEX procedure with negative selection and libraries are enriched by this method. Enriched libraries were sequenced by a new generation sequencing system Miseq using a modified metagenomics method and bioinformatics tools were used to identify candidate aptamers from high throughput data. Florescence modified DNA aptamer showed high affinity to porcine gelatine, and low affinity to fish and bovine gelatine. Aptamer generated in this study has potential use in the detection of adulteration in food as sensing agent.
\end{abstract}

\section{Giriş}

Aptamerler farklı hedeflere yüksek etkinlik ve özgünlükte bağlanabilen tek zincirli oligonükleotidlerdir. Aptamer kelimesi Latince kökenli olup "uymak" anlamına gelen "aptus" ve "bir bütünün parçası" anlamına gelen "meros" kelimelerinden üretilmiștir. Aptamerler hedeflerine farklı dizilerin oluşturduğu üç boyutlu yapı sayesinde bağlanırlar [1]. Aptamer ve hedef molekülü arasındaki etkileşim geniş bir yüzey alanında gerçekleşmektedir. Yüzey alanının geniş olması sebebi ile hedef moleküldeki en küçük değişiklikler bile aptamerin bağlanmasını engelleyebilmektedir. Srinivasan ve arkadaşlarının geliştirdiği ADP aptameri sadece bir fosfat grubu fazla olmasina rağmen ATP'ye bağlanmayarak etkin bir şekilde ayırt edebilmektedir [2].

Aptamerler bu özellikleri sayesinde, belirli bir protein ailesindeki benzer proteinleri ya da aynı proteinin farklı biçimsel durumlarını dahi birbirlerinden ayırabilmektedirler. Literatürde yer alan aptamerlerin birçoğu RNA veya tek zincir DNA molekülleridir. Bunların yanında modifiye ve sentetik nükleik asitlerden yapılmış bazı aptamerler de mevcuttur. Literatürde etanolamin, asetilkolin gibi küçük organik molekülleri $[3,4]$ büyük protein komplekslerini [5,6] hatta farklı hücreleri [7] hedef alan birçok aptamer bulunmaktadır. Aptamer-hedef kompleksleri pikomolar-submikromolar aralığında ayrışma sabiti değerlerine $\left(K_{d}\right)$ sahip olabilmektedir [8].

İlk olarak 1990'lı yıllarda 3 farklı grup tarafından birbirlerinden bağımsız olarak geliştirilen aptamerler $[5,9,10]$ bir in vitro seçme ve çoğaltma tekniği olan SELEX ile üretilmektedirler. SELEX (Systematic Evolution of Ligands by Exponential Enrichment) (Exponansiyel Zenginleştirme ile Sistematik Ligand Geliştirme) kombinasyonel bir tekniktir [5]. Bu teknikte, DNA veya RNA kütüphanelerinden hedefe 
karşı yüksek afinite gösterenler kombinasyonel teknikler kullanılarak seçilir. SELEX yönteminde ilk adım bir oligonükleotid kütüphanesi hazırlamaktır. $\mathrm{Bu}$ kütüphane rastgele dizilmiş 40 ila 80 nükleotid uzunluğunda bir merkez bölgeye sahip olan DNA ya da RNA parçalarıyla hazırlanır ve bu merkez bölgenin çeşitliliğiyle yaklaşık $10^{16}$ oligonükleotid içerir. Daha sonra bu kütüphane polimeraz zincir reaksiyonu (PZR) yardımıyla çoğaltılır ve hedefe uygulanır. Uygulamadan sonra seçilen hedefe bağlanmayan ve bağlanan DNA ayırılır. İlk aşamada hedefe bağlanan DNA, PZR yöntemi ile tekrar çoğaltılarak hedefe uygulanır. İkinci uygulama sonrasında da hedefe bağlanmayan ve bağlanan DNA ayırılır. Bu her dönüş bir SELEX turu olarak kabul edilir. SELEX turları genellikle 10 ile 12 tekrar arasında devam ettirilir ve sonuçta elde edilen DNA hedefe güçlü bağlanma özelliği taşır. Son aşamada elde edilen bu DNA dizileri dizilenerek belirlenir. SELEX yöntemiyle elde edilen bu aptamerler özgünlüklerinden dolayı çeşitli biyoteknolojik araştırmalarda, gıda endüstrisinde, hastalıkların tanı ve tedavi aşamalarında çok önemli görevler üstlenebilir.

Hileli gıdaların hızlı ve kolay tespiti günümüz şartlarında, ülkemizde her geçen gün daha önemli bir hale gelmektedir. Dünyada ve ülkemizde et ve et ürünlerinde sıklıkla karşımıza çıkan tağşiş çeşidi; değeri düşük etin veya et ürünün pahalı et yerine kullanılmasıdır. Dini hassasiyetler de göz önünde bulundurulduğunda et ve et ürünlerinde domuz katkılarının bulunması için ciddi bir problem teşkil etmektedir.

Günümüzde domuz ürünlerinin tespiti akredite laboratuvarlar tarafindan PZR veya RT-PZR temelli sistemler kullanılarak canlı DNA'sının tespitine dayanan bir metotla yapılmaktadır. $\mathrm{Bu}$ metotta sitokrom-b geninde domuza özgü dizilere primer tasarlanmakta ve hedef bölgenin çoğaltılabilmesi ile sonuç alınmaktadır. Bu tip sistemler sonuç vermesine rağmen laboratuvar ve aletlere bağımlıdır ve kesin sonuç için akredite merkezlerde yapılması gerekir. Akredite merkezlerin her yerde bulunmaması ve kullanılan metodun belirtilen alet ve teçhizatı kullanabilecek teknik elemana bağımlı olması tekniğin yerinde ve hızlı bir şekilde yapılabilmesini engellemektedir. Bunun yanında jelatin gibi ısıl işlem görmüş, asidik veya bazik hidrolize uzun süre maruz kalmış, sterilize edilmiş ve kurutulmuş et ürünlerinde hedef DNA dizisinin bütün halinde bulunabilmesi ve izole edilebilmesi zor bir süreçtir ve yanlış negatif sonuçlar verebilmektedir.

Yapılan bu araştırmada domuz jelatinine özgü aptamerler seçilip karakterize edilerek çeşitli biyosensör uygulamalarında kullanılabilecek algılama molekülleri elde edilmiştir. Geliştirilen bu algılama molekülleri QCM, SPR gibi sensör uygulamalarına kolayca adapte edilebileceği gibi kağıt veya cam tabanlı, renk değişimi temelli, taşınabilir sensörlerde de kullanılabilecektir.

\section{Materyal ve Metot}

Deneylerde kullanılan bütün kimyasallar analitik saflıkta olup aksi belirtilmedikçe Sigma-Aldrich firmasından temin edilmiştir. Çalışmada kullanılan yıkama tamponu 4,5 g/L glukoz, $\mathrm{CaCl}_{2}$ 'lı Dulbecco fosfatlı tampon salini ve $5 \mathrm{mM} \mathrm{MgCl}_{2}$ içermektedir.

\subsection{DNA kütüphanesi ve primerlerin tasarımı}

Kütüphane ve primerler tasarlanmış ve dizileri aşağıda belirtilmiştir. Kütüphanelerin ve primerlerin tasarımında Oligo analyzer 3.1, Nupack ve Mfold biyoinformatik araçları kullanılmıştır. $\mathrm{Bu}$ bağlamda Kwame ve ark. 2010 yllında Nature Methods'da yayınladığı kurallar takip edilmiştir [11]. Tasarlanan kütüphane 5'AGTCCCCTGCCCAAC CCA(44N)TCGTCGCCTCCACCACCT3', primerler ise 5FAM-AGTCCCCTGCCCAACCCA-3 ve 5-Biyotin-AGGT GGTGGAGGCGACGA-3 dizilerine sahiptir. Primer dizileri SELEX'te kullanılmak üzere 5' uçlarında biyotin ve FAM floresans modifikasyonlara sahiptir. Primer ve DNA Kütüphanesi IDTDNA tarafindan sentezlenmiştir.

\subsection{SELEX}

SELEX işlemi beş ana basamaktan oluşmaktadır(Şekil 1). İlk basamak olan bağlanma inkübasyonunda $10^{13}$ $10^{14}$ farklı dizi çeşidi içeren DNA kütüphanesi hedef molekül veya yapı ile birlikte inkübe edilmektedir. Bu çalışmada hedef olarak seçilen domuz jelatini küçük tüpler içerisinde $1 \mathrm{~mL}$ hacminde jelleştirilerek $5 \mathrm{nmol}$ kütüphane ile birlikte 30 dakika inkübe edilmiștir. Farklı dizilere sahip olması sebebi ile herbiri farklı 3 boyutlu şekiller oluşturan DNA Kütüphanesi dizilerinden uygun şekle sahip olan dizilerin bu basamakta domuz jelatini ile etkileşime girerek bağlanması beklenmiştir. İkinci basamakta ise bağlanmayan, özgün bağlanmayan ve düşük afinitelerle bağlanan dizileri ortamdan uzaklaştırmak için yıkama işlemi yapılmıştır. Yıkama için $400 \mu \mathrm{L}$ yıkama solüsyonu kullanılmış ve termomikser'de 30 saniye 300 rpm'de çalkalama yapılmıştır. Böylece jelatine yüksek afinite ile bağlanan dizilerin seçilimi hedeflenmiştir. Yıkama işlemi sonrasında hala hedefe bağlı bulunan DNA dizileri sıcaklık $95^{\circ} \mathrm{C}$ ye yükseltilerek üç boyutlu yapılarını kaybetmeleri sonucu hedeften ayırılmıștır. Elde edilen DNA dizileri SELEX tur 1 DNA havuzu olarak adlandırılmıştır. Daha sonra SELEX'in üçüncü basamağında bu DNA havuzu PZR ile çoğaltılarak çift zincirli DNA elde edilmiştir. $\mathrm{Bu}$ basamakta SELEX'in 2. turunda kullanılabilecek kadar yeterli DNA elde etmek için $1000 \mu \mathrm{L}$ hacminde bir PZR yapılmıștır. PZR $100 \mu \mathrm{L}$ 10X PZR tamponu, $80 \mu \mathrm{L}$ 2,5 mM dNTP karışımı, 50 $\mu \mathrm{L}$ (final konsantrasyonu 0,5 $\mu \mathrm{M}$ ) FAM'lı ve biyotinli primer karışımı, seçilen DNA havuzunun $500 \mu \mathrm{L}$ 'si, $270 \mu \mathrm{L}$ DNaz'sız su ve 3,0 $\mu \mathrm{L}$ Taq DNA polimeraz'dan oluşmaktadır. PZR programı $94^{\circ} \mathrm{C} 30$ saniye, $56^{\circ} \mathrm{C} 30$ saniye ve $72^{\circ} \mathrm{C}^{\prime}$ de 30 saniye olarak yapılmıștır. Elde edilen PZR ürünü SELEX'in dördüncü basamağında 
tek zincirli DNA'ya çevrilmiştir. Bunun için elde ettiğimiz çift zincirli DNA streptavidin kaplı sefaroz küreler ile inkübe edilmiş ve primerlerin birinde bulunan biyotin sayesinde güçlü bir şekilde bağlanması sağlanmıştır. Bu basamakta $1000 \mu \mathrm{L}$ PZR ürünü için $500 \mu \mathrm{L}$ streptaividin küre kullanılmıştır. Bağlanma sonrasında ortam $500 \mu \mathrm{L} 200 \mathrm{mM} \mathrm{NaOH}$ eklenerek çift zincirli DNA'nın ayrılması ve FAM içeren diğer DNA zincirinin serbest kalması sağlanmıştır. Elde edilen FAM modifiyeli tek zincirli DNA'daki NAOH'den kurtulmak için NAP5 kolonu kullanılmıştır. Elde edilen tek zincirli DNA havuzu soğuk kurutucu kullanılarak kurutulmuş ve bir sonraki turda bağlanma çözeltisinde çözülerek kullanılmaya hazır hale getirilmiştir.

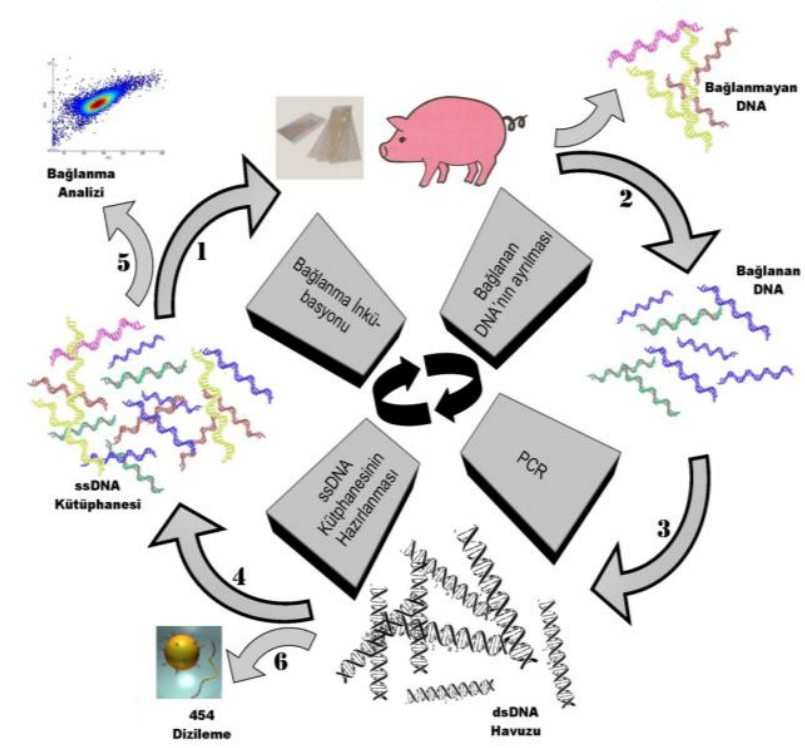

Şekil 1. Domuz jelatinine özgü aptamerlerin seçimi için uygulanan SELEX işlemi.

Elde edilen yeni DNA havuzundan 100 pmol kullanılarak aynı ișlemler tekrar edilmiștir. Bu seçilim süreci 10 tur tekrar edilerek bağlanan diziler zenginleştirilmeye çalışılmıştır.

\subsection{Dizileme ve biyoinformatik analiz}

Yapılan 10 tur SELEX sonrasında zenginleşen dizilerin belirlenebilmesi için dizileme yapılmıştır. Dizileme için MiSeq Illimuna platformu kullanılmıștır. Dizilemede 8 ve 10 no'lu SELEX DNA havuzları SELEX'te kullanılan primer dizilerini de içeren 5'TCGTCGGCAGCGTCAGATGTGTATAAGAGACAGAGT CCCCTGCCCAACCCA3' ve 5'GTCTCGTGGGCTCGGAGA TGTGTATAAGAGACAGAGGTGGTGGAGGCGACGA3' amplikon primerleri kullanılarak çoğaltılmıştır. Elde edile PZR ürünü AmpureXP küreler kullanılarak temizlenmiş sonrasında 5'AATGATACGGCGACCAC CGAGATCTACAC[i5]TCGTCGGCAGCGTC3 ve 5'CAAGC AGAAGACGGCATACGAGAT[i7]GTCTCGTGGGCTCGG3' dizileri kullanılarak index PZR yapılmıştır. İndeks PZR için SELEX 8 havuzunda i5 bölgesi yerine TAAGGCGA dizisine sahip N701 ve i7 bölgesi yerine ise TAGATCGC dizisine sahip N501, SELEX 10 havuzu için CGTACTAG dizisine sahip N702 ve N501 barkodları kullanılmıştır. $\mathrm{Bu}$ barkodlar sayesinde dizileme sonrası elde edilen dizilerin hangi havuza ait olduğu ayırt edilebilmiștir. Dizile için İllumina MiSeq sistemi kullanılmış 100 turluk tek yönlü okuma yapılmıştır. Elde edilen dizilerin Q30 altında kaliteye sahip olanları Nextgen Workbench programı kullanılarak filtrelenmiş, sonrasında 78-82 bç dizi uzunluğu aralığında bulunmayan dizier ayıklanmıştır. Elde edilen dizilerden en çok tekrar edenler Sequence Dereplicator kullanılarak belirlenmiștir. En çok tekrar eden dizilerin $4^{\circ} \mathrm{C}$ ve $37^{\circ} \mathrm{C}$ 'deki 3 boyutlu yapıları nupack [12] kullanılarak belirlenmiș ve iki sıcaklıkta yapısını koruyabilen en sık tekrarlanan dizi aptamer olarak seçilmiştir.

\subsection{Bağlanma afinitelerinin belirlenmesi}

Bağlanma deneyleri için 2500, 1500, 1000, 500, 300, 200 ve 100 pmol floresans modifikasyona sahip aptamer jelatin ile 30 dakika inkübe edilmiş ve bağlanmayan DNA miktarı Qubit ile ölçülerek belirlenmiștir. $\mathrm{K}_{\mathrm{d}}$ değeri Graph Pad Prism 6 kullanılarak $\mathrm{Y}=\mathrm{B}_{\max } \mathrm{X} /\left(\mathrm{K}_{\mathrm{d}}+\mathrm{X}\right)$ formülüne göre hesaplanmıştır.

\section{Bulgular}

\subsection{Aptamer adaylarının zenginleştirilmesi}

Çalışmamızda domuz jelatinine karşı aptamerlerin geliştirilmesi için SELEX yöntemi (Şekil 1) pozitif ve negatif seçilimlerle başarılı bir şekilde uygulanmıştır. SELEX kapsamında domuz jelatinine karşı pozitif seçilim yapılırken balık ve inek jelatinleri karıştırılarak negatif seçilimde kullanılmıştır. Bu sayede domuz jelatinini diğer jelatinlerden ayırt edebilen bir aptamer yapılması hedeflenmiştir. Seçilim esnasında zenginleștirilen havuzların bağlanma etkinliklerinin belirlenmesi için tek zincirli hale getirilen DNA havuzlarının hedef domuz jelatini ve balık-inek jelatini karışımına bağlanma etkinlikleri ölçülerek zenginleşme ölçülmüştür. Şekil 2'de görüldüğü gibi SELEX süreci boyunca seçilen havuzların hedef domuz jelatinini balık-inek jelatinine göre daha iyi bağlanmaktadır. SELEX'in ilk turlarında bağlanma etkinliklerindeki fark az olsa da SELEX koşullarının (yıkama sayısının arttırılması, inkübasyonu süresinin düşürülmesi vb.) daha seçici hale getirilmesi ile yükselmiştir. Her ne kadar 10 turluk bu SELEX sürecinde DNA havuzlarının bağlanma miktarı düşmüş gibi görünse de aslında seçiciliği yükselmektedir. Yani elde edilen DNA havuzlarında domuz jelatinine bağlanan ama diğer jelatinlere bağlanmayan DNA dizileri artmaktadır.

Yapılan 10 turluk seçilim sonrasında 8 ve 10 . tur ürünlerine yapılan dizileme sonrasında elde edilen dizi profili Şekil 3'de görülmektedir. Profil incelendiğinde elde edilen dizilerin ilk ve son 18 nükleotidlerinin sabit primer dizlerinden oluştuğu 
ortada bulunan dizilerde ise adenin ağırlıklı ama eşit dağılımlı dizilerden oluştuğu gözlemlenmektedir.

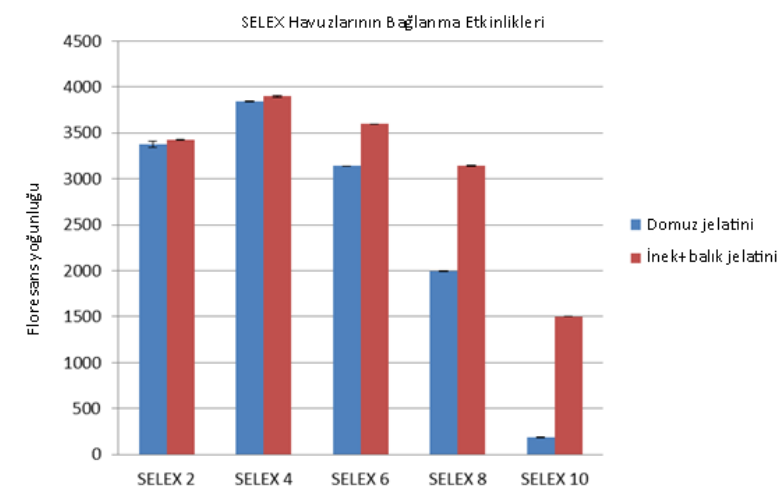

Şekil 2. SELEX havuzlarının farklı jelatinlere bağlanma etkinlikleri (Süpernatantta bulunan floresans miktarı).

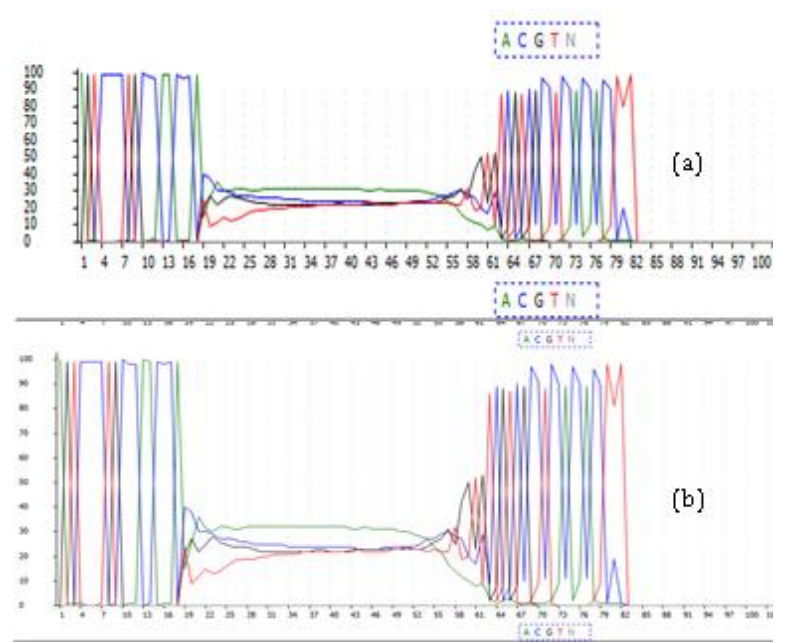

Şekil 3. SELEX 8 (a) ve SELEX 10 (b) dizi profili.

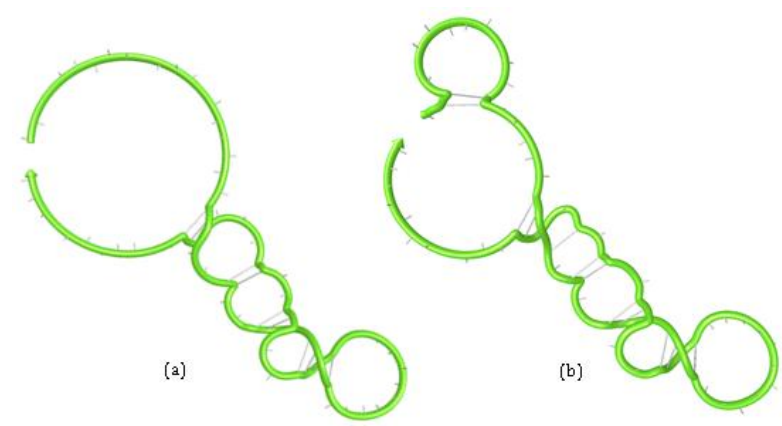

Şekil 4. Jelatin aptamerinin $37^{\circ} \mathrm{C}$ (a) ve $4^{\circ} \mathrm{C}$ 'de oluşturduğu 3 boyutlu şekil.

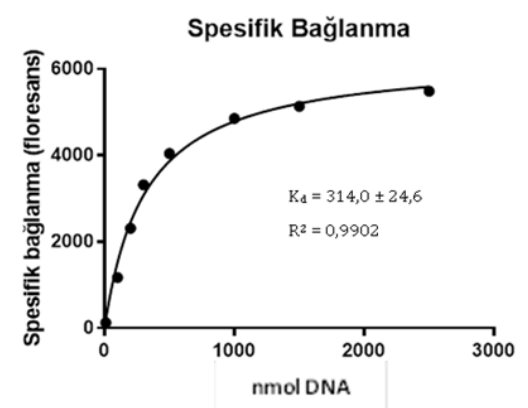

Şekil 5. Domuz jelatini ve aptamer arasındaki bağlanma eğrisi.
Verilerin değerlendirilmesinde sekans çoğaltıcı (sequence dereplicator) biyoinformatik programı kullanılmıștır. Yapılan sekans çoğaltıcı işlem sonucu 5'AGTCCCCTGCCCAACCCATAGCGCTACCAACAAGATC CGTCTGCATTAGATCTCCTGTCCGTCGTCGCCTCCACCA CCT3' dizisinin iki DNA havuzunda da en çok tekrar eden dizi olduğu belirlenmiş ve aday aptamer olarak belirlenmiştir. Elde edilen dizinin $4^{\circ} \mathrm{C}$ ve $37^{\circ} \mathrm{C}$ 'de oluşturduğu 3 boyutlu yapı birbirine oldukça benzemektedir (Şekil 4).

\subsection{Aptamerlerin bağlanma özgünlüklerinin belirlenmesi}

Elde edilen aptamer dizisinin domuz jelatinine yönelik bağlanma afinitesi $\left(\mathrm{K}_{\mathrm{d}}\right) 314,0 \pm 24,6 \mathrm{nM}$ olarak belirlenmiştir (Şekil 5).

Elde edilen DNA aptamerinin farklı jelatinlere karşı bağlanma etkinliklerinin belirlenmesi için yapılan deneyler sonrasında aptamerin balık ve inek jelatinini istatistiksel olarak anlamlı bir şekilde domuz jelatininden ayırabildiği gözlemlenmiştir (Şekil 6).

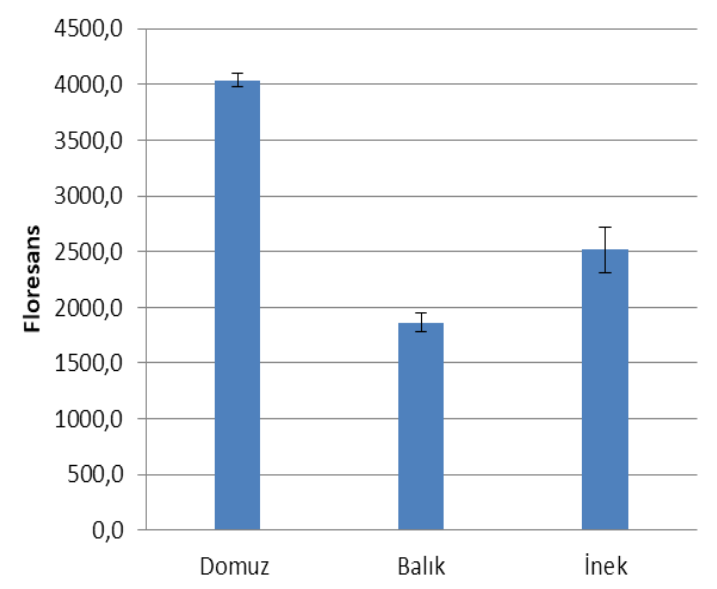

Şekil 6. Jelatin aptamerinin farklı jelatin türlerine bağlanma etkinliği.

\section{Tartışma ve Sonuç}

Bu çalışma kapsamında çok turlu bir SELEX yapılarak domuz jelatinini ayırt edebilen bir aptamer seçilmiştir ve bu literatürde bulunan ilk jelatin aptameridir. Seçilen aptamer mikromolar aralıkta bir $\mathrm{K}_{d}$ değerine sahiptir ve bu düșük afinite sayesinde gıda tağşişlerinde kullanılabilecek seviyededir. Elde edilen aptamer farklı biyosensör platformlarında kullanılarak özellikle helal ve kosher gıda için oldukça önemli ve algılanması zor bir hedef olan domuz jelatinini algılayabilecek kapasiteye sahiptir.

\section{Teşekkür}

$\mathrm{Bu}$ çalışmayı 17-M-13 no'lu proje kapsamında destekleyen Karamanoğlu Mehmetbey Üniversitesi'ne teşekkür ederiz. 


\section{Kaynakça}

[1] Proske, D., Blank, M., Buhmann, R., Resch, A. 2005. Aptamers- basic research, drug development, and clinical applications. Applied Microbial Biotechnology, 69, 367-374.

[2] Srinivasan, J., Cload, S. T., Hamaguchi, N., Kurz, J., Keene, S., Kurz, M., Boomer, R. M., Blanchard, J., Epstein, D., Wilson, C., Diener, J. L., 2004. ADPspecific sensors enable universal assay of protein kinase activity. Chem Biol., 11(4), 499508.

[3] Mann, D., Reinemann, C., Stoltenburg, R., Strehlitz, B. 2005. In vitro selection of DNA aptamers binding ethanolamine. Biochemical and Biophysical Research Communications, 338 (4), 1928-1934.

[4] Bruno, J. G., Carrillo, M. P., Phillips, T., King, B. 2008. Development of DNA aptamers for cytochemical detection of acetylcholine. In vitro Cellular \& Developmental Biology. Animal, 44 (3-4), 63-72.

[5] Tuerk, C., Gold, L. 1990. Systematic evolution of ligands by exponential enrichment: RNA ligands to bacteriophage T4 DNA polymerase. Science, 249 (4968), 505-510.

[6] Bock, L. C. Griffin, L. C., Latham, J. A., Vermaas, E.H., Toole, J.J. 1992. Selection of single-stranded DNA molecules that bind and inhibit human thrombin, Nature, 355 (6360), 564-566.

[7] Bayrac, A. T., Sefah, K., Parekh, P., Bayrac, C., Gulbakan, B., Oktem, H. A., Tan, W. 2011. In Vitro Selection of DNA Aptamers to Glioblastoma Multiforme. ACS Chemical Neuroscience, 2 (3), 175-181.

[8] Hamula, Camille L.A, Chris, L., Xing-Fang, L. 2011 DNA aptamers binding to multiple prevalent Mtypes of Streptococcus pyogenes. Analytical chemistry 83(10), 3640-3647.

[9] Robertson, D. L., Joyce, G. F. 1990. Selection in vitro of an RNA enzyme that specifically cleaves single-stranded DNA. Nature, 344 (6265), 467468.

[10] Ellington, A. D., Szostak, J. W. 1990. In vitro selection of RNA molecules that bind specific ligands. Nature, 346 (6287), 818-822.

[11] Sefah, K., Shangguan, D., Xiong, X., O'donoghue, M. B., \& Tan, W. 2010. Development of DNA aptamers using Cell-SELEX. Nature Protocols, 5(6), 1169-1185.

[12] Zadeh, J.N., Steenberg, C.D., Bois, J.S., Wolfe, B.R., Pierce, M.B., Khan, A.R., Dirks, R.M., Pierce, N.A. 2011. NUPACK: analysis and design of nucleic acid systems. J Comput Chem, 32, pp.170-173 